Volume 11, Nomor 2, November 2019, pp 211-217 Copyright (C) 2017 Jurnal Akuntansi Maranatha, Program Studi Akuntansi, Fakultas Ekonomi, Universitas Kristen Maranatha. ISSN 2085-8698 | e-ISSN 2598-4977. http://journal.maranatha.edu

\title{
Pengaruh Leverage dan Liquidity Terhadap Tax Avoidance Dengan Inventory Intensity Sebagai Variabel Moderasi
}

\author{
David Malindo Pasaribu \\ FEIB Program Studi Magister Akuntansi-Univ. Trisakti \\ (Jl. Kyai Tapa No 1, Grogol, Jakarta Barat) \\ david.m.p1000@gmail.com \\ Susi Dwi Mulyani \\ FEIB Program Studi Magister Akuntansi-Univ. Trisakti \\ (Jl. Kyai Tapa No 1, Grogol, Jakarta Barat) \\ susi.dwimulyani@yahoo.com
}

\begin{abstract}
This study aims to analyze the effect of leverage and liquidity on tax avoidance with inventory intensity as a moderating variable. The type of data used is secondary data. The sample used is a manufacturing company that is listed active in BEI Period 2015-2017 which can be seen on the official website that www.idx.co.id. Methods of data analysis using is moderated regression analysis (MRA). Data processing is done by using Eviews Version 10 for windows. The results showed that there is a significant negative effect between liquidity with tax avoidance, there is a significant negative influence between inventory intensity with tax avoidance, inventory intensity was able to moderate the effect of liquidity to tax avoidance. In addition, the leverage did not effect to tax avoidance, the inventory intensity was not able to moderate the effect of leverage to tax avoidance.
\end{abstract}

Keywords: Leverage, Liquidity, Tax Avoidance, and Inventory Intensity

\section{Pendahuluan}

Pajak merupakan sumber pendapatan negara yang terbesar, yaitu 1.343,5 trilliun rupiah $(98,6$ persen) dari total pendapatan negara 1.362 triliun rupiah dalam APBN-P 2017 (www.kemenkeu.go.id). Penerimaan tersebut antara lain digunakan untuk meningkatkan pendidikan dan kesejahteraan rakyat, membangun infrastruktur pendorong pertumbuhan ekonomi, mendukung ketahanan dan keamanan, serta untuk pembangunan di daerah (RAPBN 2017).

Menurut World Economic Forum (WEF), lembaga non-profit yang didirikan di Jenewa, Swiss merilis indeks daya saing infrastruktur negara-negara di dunia. Pada periode 2015-2016 Indonesia menduduki posisi 62, periode 2016-2017 pada posisi 41, dan pada periode $2017-2018$ pada posisi 36 (liputan6.com diakses pada tanggal 19 April 2018 pukul 06.16 WIB). Hal ini 
menunjukkan bahwa tingkat pembangunan infrastruktur di Indonesia semakin meningkat dari tahun ke tahun. Dalam pembangunan infrastruktur diperlukan sumber dukungan dana yang cukup besar. Sumber dana tersebut dapat berasal dari dalam negeri maupun luar negeri. Salah satu sumber dana yang berasal dari dalam negeri berasal dari pajak.

Oleh karena itu persoalan tax avoidance merupakan persoalan yang unik dan rumit karena di satu sisi tax avoidance tidak melanggar hukum, tapi disisi lain tax avoidance tidak diinginkan oleh pemerintah. Penghindaran pajak yang dilakukan perusahaan biasanya dipengaruhi oleh rasio keuangan.

Leverage yaitu rasio yang dipergunakan untuk mengukur sejauh mana perusahaan dibiayai dengan menggunakan utang (Kasmir, 2013:151). Berkaitan dengan leverage, hasil penelitian yang dilakukan oleh Siregar \& Widyawati (2016), Suyanto dan Supramono (2012) mengatakan bahwa leverage berpengaruh positif signifikan terhadap tindakan penghindaran pajak (tax avoidance).

Pajak merupakan salah satu bagian dari kewajiban jangka pendek perusahaan. Kemampuan perusahaan untuk melaksanakan kewajiban jangka pendeknya dapat dilihat dari rasio likuiditas. Kewajiban jangka pendek akan mampu dipenuhi apabila rasio likuiditas perusahaan sedang dalam keadaan yang tinggi (Suyanto dan Supramono, 2012). Menurut hasil penelitian Anita M (2015) menunjukkan bahwa perusahaan dengan kondisi likuiditas yang rendah cenderung akan berperilaku agresif terhadap pajak supaya perusahaan dapat mempertahankan arus kasnya untuk memenuhi kewajiban jangka pendeknya.

Tingkat persediaan atau Inventory Intensity Ratio yang tinggi juga dapat mengurangi jumlah pajak yang dibayar perusahaan. Hal ini karena timbulnya beban-beban bagi perusahaan akibat dari adanya persediaan (Herjanto, 2007). Penelitian yang dilakukan oleh Anindyka,
Dimas et al (2018) mengenai pengaruh leverage (DAR), capital intensity dan inventory intensity terhadap agresivitas pajak memperoleh hasil bahwa inventory intensity mempunyai pengaruh negatif pada agresivitas pajak.

Tujuan utama penelitian ini dilakukan adalah untuk mencari informasi terkait dengan ketaatan perusahaan dalam membayar pajak atau perusahaan melakukan tindakan penghindaran pajak.

Penelitian ini diharapkan dapat memberikan manfaat bagi berbagai pihak. Manfaat yang diharapkan dari penelitian ini antara lain:

1. Manfaat teoritis

Penelitian ini diharapkan dapat dijadikan sebagai acuan dalam pengembangan ilmu ekonomi, khususnya bidang akuntansi perpajakan.

2. Manfaat praktis

Penelitian ini diharapkan dapat memberikan informasi bagi pihak terkait dengan keputusan atau kebijakan yang akan diambil.

\section{Kerangka Teoritis dan Hipotesis}

\section{Teory Agensi (Agency Theory)}

Teori keagenan menyatakan bahwa hubungan keagenan sebagai kontrak antara satu atau beberapa orang (principals) yang mempekerjakan orang lain (agent) untuk melakukan sejumlah jasa dan memberikan wewenang dalam pengambilan keputusan. (Jensen dan Meckling, 1976). Dalam teori keagenan, manajemen perusahaan menyajikan laporan keuangannya berdasarkan: (1) motivasi opportunistic, dimana motivasi tersebut mendorong manajemen untuk melakukan manajemen laba sehingga laba yang disajikan dalam laporan keuangan menjadi lebih tinggi demi mendapatkan insentif, (2) motivasi signaling, dimana manajemen akan menyajikan laporan keuangan yang berkualitas agar menimbulkan sinyal positif terhadap investor dan sebagai evaluasi kinerja manajemen. 


\section{Tax Avoidance}

Merupakan suatu cara mengurangi pajak yang masih dalam batas ketentuan peraturan perundang-undangan perpajakan dan dapat dibenarkan, terutama melalui perencanaan pajak (Santoso dan Rahayu, 2013:4). Penghindaran pajak dapat dikategorikan sebagai tindakan yang legal sepanjang dilakukan melalui suatu perencanaan dan tidak melanggar peraturan pajak yang berlaku serta dilakukan dengan tujuan untuk menunda atau mengalihkan pembebanan pajak ke periode berikutnya sehingga beban pajak pada periode berjalan tidak memberatkan bahkan sampai mengganggu cash flow perusahaan.

\section{Leverage}

Leverage merupakan rasio yang menunjukkan besarnya utang yang dimiliki perusahaan untuk membiayai aktivitas operasinya (Darmawan dan Sukartha, 2014). Leverage sebagai rasio yang timbul apabila dalam kegiatan operasionalnya perusahaan menggunakan dana pinjaman atau menggunakan dana yang memiliki beban bunga (Siswianti dan Kiswanto, 2016).

\section{Liquidity}

Likuditas mengacu pada kemampuan perusahaan untuk memenuhi kewajiban jangka pendeknya. Likuiditas merupakan kemampuan untuk mengubah aktiva menjadi kas atau kemampuan untuk memperoleh kas (Wild, et al, 2004 : 185). Kemampuan perusahaan untuk melaksanakan kewajiban jangka pendeknya dapat dilihat dari rasio likuiditas, apabila perusahaan memiliki rasio likuiditas yang tinggi maka perusahaan tersebut sedang berada dalam kondisi arus kas yang lancar, sehingga kewajiban jangka pendek akan mampu dipenuhi (Adisamartha dan Noviari, 2015).

\section{Inventory Intensity}

Inventory intensity atau intensitas persediaan merupakan perbandingan antara total persediaan terhadap total aset (Lanis dan Richardson, 2011). Inventory intensity atau bisa disebut juga dengan intensitas persediaan merupakan salah satu komponen penyusun aktiva yang diukur dengan membandingkan antara total persediaan dengan total aset yang dimiliki perusahaan (Siregar dan Widyawati, 2016).

\section{Pengembangan Hipotesis}

\section{Pengaruh Leverage terhadap Tax Avoidance}

Rasio leverage yang tinggi menunjukkan besarnya jumlah pendanaan perusahaan yang bersumber dari utang, sehingga akan menimbulkan jumlah beban bunga yang tinggi yang dapat mengurangi laba sehingga akan menurunkan beban pajak perusahaan. Penelitian terkait leverage pernah dilakukan oleh Marfirah dan Syam (2016) yang menemukan bahwa leverage berpengaruh negatif terhadap tax avoidance. Berdasarkan uraian tersebut, maka hipotesis yang dirumuskan adalah:

$\mathrm{H} 1:$ Leverage berpengaruh negatif
terhadap tax avoidance.

\section{Pengaruh Liquidity terhadap Tax Avoidance}

Perusahaan yang memiliki likuiditas tinggi akan mencerminkan kondisi keuangan yang baik sehingga perusahaan akan memiliki kemampuan untuk membayar seluruh kewajibannya termasuk kewajiban membayar pajak, sebaliknya perusahaan yang likuiditasnya rendah maka akan lebih memilih untuk menjaga cash flows daripada harus membayar beban pajak demi mengamankan keuangan perusahaan. Sehingga terdapat hubungan antara likuiditas terhadap penghindaran pajak ( $\operatorname{tax}$ avoidance). Sesuai hasil penelitian yang dilakukan oleh Siahaan (2005) yang menyatakan bahwa likuiditas berpengaruh negatif terhadap penghindaran pajak (tax avoidance). Berdasarkan hal tersebut diatas 
maka penulis merumuskan hipotesis sebagai berikut :

H2: Liquidity berpengaruh negatif terhadap tax avoidance.

\section{Pengaruh Inventory Intensity terhadap} Tax Avoidance

Inventory intensity merupakan salah satuukuran kinerja perusahaan yang menggambarkan seberapa besar proporsi persediaan barang dagangan terhadap total aset yang dimiliki oleh perusahaan. Semakin tinggi nilai persediaan mencerminkan semakin rendahnya nilai harga pokok penjualan sehingga akan menyebabkan laba perusahaan dan beban pajak yang semakin tinggi. Sesuai sudut pandang bisnis bahwa ketika inventory intensity dapat mempengaruhi peningkatan laba dan beban pajak maka perusahaan akan berusaha memaksimalkan laba dan meminimalkan biaya dengan merancang cara melalui perencanaan pajak (tax planning) yang efektif melalui skema penghindaran pajak (tax avoidance). Berdasarkan uraian tersebut, maka hipotesis yang dirumuskan adalah:

H3: Inventory intensityberpengaruh negatif terhadap tax avoidance.

Pengaruh Inventory Intensity pada Leverage dan Tax Avoidance

Pendefinisian leverage berhubungan dengan penggunaan utang untuk operasional perusahaan yang menyebabkan timbulnya bunga. Perusahaan yang memiliki inventory intensity yang tinggi akan berusaha memaksimalkan laba dan meminimalkan beban pajak. Berdasarkan uraian tersebut, maka hipotesis yang dirumuskan adalah:

$\mathrm{H} 4$ : Inventory intensity memperlemah pengaruh leverage terhadap tax avoidance.
Pengaruh Inventory Intensity pada Liquidity dan Tax Avoidance

Perusahaan yang memiliki likuiditas tinggi akan mencerminkan kondisi keuangan yang baik sehingga perusahaan akan memiliki kemampuan untuk membayar seluruh kewajibannya termasuk kewajiban membayar pajak. Semakin tinggi inventory intensity akan membuat pembayaran pajak semakin tinggi. Berdasarkan uraian tersebut, maka hipotesis yang dirumuskan adalah:

H5: Inventory intensity memperkuat pengaruh liquidity terhadap tax avoidance.

Model kerangka konseptual dapat dilihat pada gambar sebagai berikut:

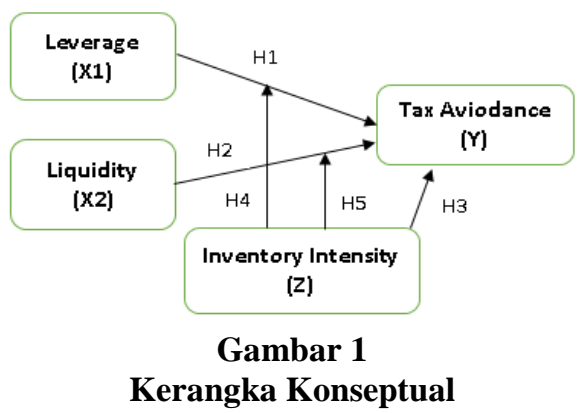

Skema hubungan antara tax avoidance dengan variabel-variabel yang mempengaruhinya dapat digambarkan sebagai berikut:

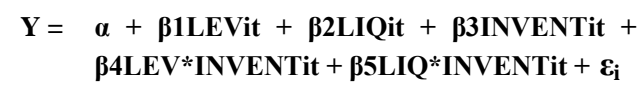

Keterangan:

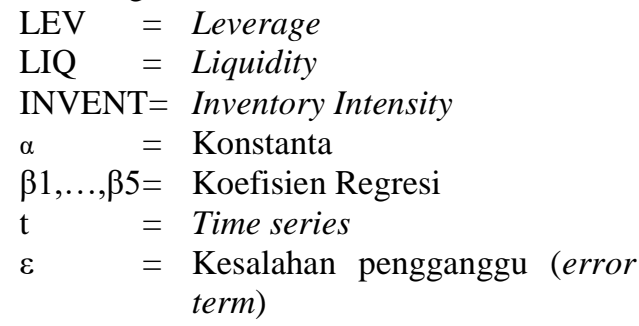




\section{Metode Penelitian}

\section{Jenis Penelitian}

Pendekatan yang dilakukan dalam penelitian ini adalah pendekatan kuantitatif. Metode penelitian kuantitatif menurut Sugiyono (2015:7) adalah metode penelitian yang berlandaskan pada filsafat positivisme, pengumpulan data menggunakan instrumen penelitian, analisis data bersifat kuantitatif atau statistik, dengan tujuan untuk menguji hipotesis yang telah ditetapkan.

\section{Populasi dan Sampel}

Populasi dalam penelitian ini adalah seluruh perusahaan manufaktur yang terdaftar di Bursa Efek Indonesia.Sampel yang digunakan dalam penelitian ini diambil dengan mengunakan pendekatan purposive sampling, yaitu tidak semua populasi dijadikan sampel namun hanya populasi dengan kriteria dan pertimbangan tertentu saja yang dijadikan sampel (Sugiyono, 2012, 122).

Adapun kriteria atau pertimbangan pengambilan sampel yang digunakan penulis adalah:

1. Perusahaan manufaktur yang telah terdaftar di Bursa Efek Indonesia tahun $2015-2017$.

2. laporan keuangannya menggunakan satuan mata uang rupiah

3. menyajikan laporan keuangan yang berakhir pada tanggal 31 Desember.

4. Tidak mengalami kerugian selama tahun penelitian.

5. Tidak mengalami lebih bayar selama tahun penelitian.

\section{Hasil Penelitian dan Pembahasan}

\section{Pemilihan Model Regresi Data Panel}

Tabel 1

Hasil Uji Lagrange Multiplier

\begin{tabular}{lccc}
\hline \hline & \multicolumn{3}{c}{ Test Hypothesis } \\
& $\begin{array}{c}\text { Cross- } \\
\text { section }\end{array}$ & Time & Both \\
\hline \hline Breusch-Pagan & 3.950278 & 0.772262 & 4.722540 \\
& $(0.0469)$ & $(0.3795)$ & $(0.0298)$
\end{tabular}

Berdasarkan tabel 1, diperoleh nilai probabilitas Breusch-Pagan (BP) sebesar 0.0298 lebih besar dari taraf signifikansi $5 \%$ menunjukkan bahwa nilai probabilitas (p-value) $<0,05$ maka sesuai dengan ketentuan pengambilan keputusan bahwa penelitian ini menggunakan metode random effect.

\section{Uji Hipotesis}

Dalam penelitian ini, peneliti melakukan uji hipotesis dengan taraf kepercayaan 95\%, dengan syarat sebagai berikut:

1. Tolak hipotesis, jika nilai signifikansi hitung lebih besar atau sama dengan $\alpha=0.05$, yang berarti tidak terdapat pengaruh antara independen variabel terhadap dependen variabel.

2. Terima hipotesis, jika nilai signifikansi hitung lebih besar atau sama dengan $\alpha=0.05$, yang berarti terdapat pengaruh antara independen variabel terhadap dependen variabel.

Berdasakan pengolahan data, maka peneliti menemukan hasil sebagai berikut:

Tabel 2

Hasil Pengaruh Parsial

\begin{tabular}{|c|c|c|}
\hline Variable & t-Statistic & Prob. Kesimpulan \\
\hline $\mathrm{C}$ & -1.924529 & 0.0565 \\
\hline LEV & -1.345946 & $0.1807 \mathrm{H} 1$ ditolak \\
\hline LIQ & -4.104809 & $0.0001 \mathrm{H} 2$ diterima \\
\hline TNVENT & -2.560413 & $0.0116 \mathrm{H} 3$ diterima \\
\hline LEV_INVENT & 1.579037 & $0.1168 \mathrm{H} 4$ ditolak \\
\hline LIQ_TNVENT & 3.467213 & $0.0007 \mathrm{H} 5 \mid$ diterima \\
\hline
\end{tabular}


Berdasarkan tabel 2, dapat disimpulkan bahwa :

1. Pengujian hipotesis pertama (H1)

Nilai $t_{\text {hitung }}$ variabel LEV sebesar -1.345946 dengan p-value sebesar 0.1807. Dikarenakan nilai prob. (pvalue) $>0.05$ (taraf signifikansi $5 \%$ ) atau $0.1807>0.05$, maka $\mathrm{H} 0$ diterima dan diperoleh kesimpulan bahwa leverage tidak berpengaruh terhadap tax avoidance.

2. Pengujian hipotesis kedua (H2)

Nilai $t_{\text {hitung }}$ variabel LIQ sebesar -4.104809 dengan p-value sebesar 0.0001. Dikarenakan nilai prob. (pvalue) $<0.05$ (taraf signifikansi 5\%) atau $0.0001<0.05$, maka H0 ditolak dan diperoleh kesimpulan bahwa liquidity berpengaruh negatif terhadap tax avoidance.

3. Pengujian hipotesis ketiga (H3)

Nilai $t_{\text {hitung }}$ variabel INVENT sebesar -2.560413 dengan $p$-value sebesar 0.0116. Dikarenakan nilai prob. (pvalue) $<0.05$ (taraf signifikansi $5 \%$ ) atau $0.0116<0.05$, maka H0 ditolak dan diperoleh kesimpulan bahwa inventory intensity berpengaruh negatif terhadap tax avoidance.

4. Pengujian hipotesis ketiga (H4)

Nilai $t_{\text {hitung }}$ variabel LEV $^{*}$ INVENT sebesar 1.579037 dengan p-value sebesar 0.1168. Dikarenakan nilai prob. (p-value) $>0.05$ (taraf signifikansi 5\%) atau $0.1168>0.05$, maka H0 diterima dan diperoleh kesimpulan bahwa leverage dimoderasi inventory intensity ratio tidak mempunyai pengaruh yang signifikan terhadap tax avoidance.

5. Pengujian hipotesis ketiga (H5)

Nilai $t_{\text {hitung }}$ variabel LIQ*INVENT sebesar 3.467213 dengan p-value sebesar 0.0007. Dikarenakan nilai prob. (p-value) $<0.05$ (taraf signifikansi 5\%) atau $0.0007<0.05$, maka H0 ditolak dan diperoleh kesimpulan bahwa inventory intensity memperkuat pengaruh liquidity terhadap tax avoidance.

\section{Simpulan dan Saran}

\section{Simpulan}

Hasil penelitian ini menunjukkan bahwa liquidity dan inventory intensity berpengaruh negatif terhadap tax avoidance dan inventory intensity memperkuat pengaruh liquidity terhadap tax avoidance, sedangkan leverage tidak berpengaruh terhadap tax avoidance dan inventory intensity tidak memoderasi pengaruh leverage terhadap tax avoidance.

\section{Keterbatasan}

Masih adanya keterbatasan dalam penelitian ini yang masih perlu direvisi untuk penelitian selanjutnya, antara lain:

1. Masih terdapat variabel lain yang belum digunakan yang memiliki kontribusi yang besar dalam mempengaruhi yang terjadi dalam sebuah perusahaan.

2. Sampel yang digunakan hanya menggunakan perusahaan manufaktur.

\section{Saran}

Berdasarkan hasil penelitian, peneliti mengungkapkan saran sebagai berikut:

1. Bagi peneliti, sebaiknya menganalisa berbagai sektor perusahaan selain manufaktur pada sub sektor industri dasar dan kimia, sehingga menghasilkan hasil penelitian yang lebih bervariasi lagi.

2. Untuk penelitian selanjutnya, peneliti dapat menambahkan variabel-variabel lain yang ada diluar model penelitian untuk mendapatkan hasil yang lebih bervariasi dan lebih baik lagi.

\section{Daftar Pustaka}

Adisamartha, I.B.P.F., dan Noviari, N. 2015. Pengaruh Likuiditas, Leverage,Intensitas Persediaan Dan Intensitas Aset Tetap Pada Tingkat AgresivitasWajib Pajak Badan. E-Jurnal akuntansi universitas udayana, Vol 13, No.3,Desember 2015, hal 977-978, 980, 994-995 
Anindyka S, Dimas, dkk, 2018. pengaruh leverage (dar), capital intensity dan inventory intensity terhadap tax avoidance dalam e-Proceeding of Management : Vol.5, No.1. ISSN: 23559357.

Anita M, Fitri. 2015. "Pengaruh Corporate Social Responsibility, Leverage, Likuiditas dan Ukuran Perusahaan terhadap Agresivitas Pajak" dalam Jom FEKON Volume 2 Nomor 2. Pekanbaru: Fakultas Ekonomi Universitas Riau.

Darmawan, I. G. H., \& Sukartha, I. M. (2014). Pengaruh Penerapan Corporate Governance, Leverage, Return On Assets, dan Ukuran Perusahaan pada Penghindaran Pajak. E-Jurnal Akuntansi Universitas Udayana 9.1.

Herjanto, Eddy. 2007. Manajemen Operasi. Jakarta: Grasindo.

Jensen \& Meckling, 1976, The Theory of the firm: Manajerial Behavior, Agency Cost, and Ownership Structure, Journal of Financial and Economics, 3:305-360

Kasmir. Analisis Laporan Keuangan. Jakarta, Rajawali Pers, 2015.

Lanis, R. and Grant Richardson. 2011. The Effect of Board Director Composition on Corporate Tax Aggressiveness. Journal of Accounting and Public Policy 30 (1), 50-70.

Marfirah, Dina, dan Fazli Syam BZ. 2016. "Pengaruh Corporate Governance danLeverage terhadap Tax Avoidancepada Perusahaan Manufaktur yangterdaftar di Bursa Efek Indonesia (BEI) Tahun 2011-2015." Jurnal IlmiahMahasiswa Ekonomi Akuntansi.

Santoso, Iman dan Rahayu, Ning. (2013). Corporate Tax Management. Observationand Research of Taxation (Ortax). Jakarta.

Siahaan, F. O. (2005). Faktor-Faktor yang Memengaruhi Perilaku Kepatuhan TaxProfessional dalam Pelaporan Pajak Badanpada Perusahaan Industri Manufaktur diSurabaya. Tesis. Program Pasca SarjanaUniversitas Airlangga.
Siregar, Widyawati. 2016. Pengaruh Karakteristik Perusahaan Terhadap Penghindaran Pajak Pada Perusahaan Manufaktur Di BEI. Jurnal Ilmu Dan Riset Akuntansi 5 (2). ISSN : 24600585 .

Siswianti dan Kiswanto, 2016, Analisis Determinan Tax Aggressiveness PadaPerusahaan Multinasional, Accounting Analysis Journal ISSN 2252-6765,Universitas Negeri Semarang.

Sugiyono.(2012). Metode Penelitian Bisnis. Bandung: Alfabeta.

Sugiyono. 2015. Metode Penelitian Pendidikan (Pendekatan Kuantitatif, Kualitatif dan R\&D). Penerbit CV. Alfabeta: Bandung.

Suyanto, Supramono. 2012. Likuiditas, Leverage, Komisaris Independen Dan Manajemen Laba Terhadap Agresivitas Pajak Perusahaan. Jurnal Keuangan dan Perbankan 16 (2) : 167-177.

Wild S, Roglic G \& Green A, et al. 2004. Global Prevalence of Diabetes. Diabetes Care 27:1047-1053.

\section{Internet:}

www.idx.co.id

www.kemenkeu.go.id

Liputan6.com 